\author{
Commerce Division \\ Discussion Paper No. 65
}

\title{
CLASSIFICATION OF FOREIGN OPERATIONS FOR FINANCIAL REPORTING
}

\author{
Fawzi Laswad* \\ Melvin Roush**
}

February 1999

Commerce Division

PO Box 84

Lincoln University

CANTERBURY

Telephone No: (64) (3) 3252811

Fax No: (64) (3) 3253847

E-mail: laswad@kea.lincoln.ac.nz

ISSN 1174-5045

ISBN 1-877176-42-7 
* $\quad$ Fawzi Laswad, Professor of Accounting, Commerce Division, Lincoln University, Canterbury, New Zealand

** Melvin Roush, Senior Lecturer, Victoria University of Wellington, Wellington, New Zealand 


\section{Abstract}

The New Zealand (NZ) standard on foreign currency translation (FRS-21), similar to standards in the US, Australia, and Canada and the International Accounting Standard (IAS21), requires the classification of foreign operations for translation purposes into two mutually exclusive types: integrated or independent. In judging whether a foreign operation is either integrated or independent, the accounting standard requires the evaluation of five qualitative factors. The standard neither describes the judgement process nor identifies the relative importance of the determining factors.

It has been asserted that the lack of clarity in the standard on foreign currency translation may yield dissimilar results for firms whose circumstances are similar and consequently may reduce the comparability of financial statements across firms.

Using a repeated measures design, this paper examines the judgement of preparers of financial statements (New Zealand financial controllers) in determining the designation of foreign operations for translation purposes. The results indicate that the relative importance of the determining factors is marginally unequal. No support is found for the assertion that the use of qualitative factors in accounting standards results in dissimilar judgements (lack of consensus) across respondents. Further, the results show that the subjects demonstrated consistency and self-insight in their judgements. Further, the results indicate that the judgements of respondents are not biased toward either classification of foreign operation. This may suggest that the observed bias may be motivated by economic factors rather than the outcome of using the qualitative cues in the accounting standard. When the respondents were debriefed, several of them identified 'managerial independence' as another determining factor that has not been included in the NZ standard. 


\section{Contents}

List of Tables $\quad$ i

1. Introduction 1

2. Accounting Standards on Foreign Currency Translations 2

3. Literature Review 3

4. Hypotheses 5

4.1 Cue Utilisation 6

$\begin{array}{lll}4.2 & \text { Consensus } & 7\end{array}$

4.3 Consistency 7

4.4 Self-Insight 8

4.5 Bias 8

5. Research Design 8

5.1 Method 8

5.2 Subjects 9

6. Data Analysis and Results 12

$\begin{array}{ll}\text { 7. Summary and Conclusions } & 15\end{array}$

$\begin{array}{ll}\text { References } & 17\end{array}$ 


\section{List of Tables}

1. Panel A: Independent Variables and Their Levels

Panel B: An Example of a Hypothetical Judgement Set

2. ANOVA Model Results 


\section{Introduction}

The translation of foreign operations' financial statements has economic consequences for investors (parents or reporting entities) since the selection of a translation method affects reported earnings (for example; Griffin, 1982; Ziebart and Kim, 1987; Garlicki, Fabozzi, and Fonfeder, 1987; Doupnik and Evans, 1988; and Chen, Comiskey, and Mulford, 1990). These economic consequences have influenced the development of accounting standards on foreign currency translation (for example, Kelly, 1985; and Kirsch, Evans, and Doupnik, 1990). ${ }^{1}$ Further, these standards allow the exercise of considerable judgement in the determination of the translation method (for example, Amernic and Galvin, 1984). This paper examines the judgement processes of preparers (New Zealand financial controllers) in deciding the designation of foreign operations.

Similar to other international accounting standards, the NZ standard on foreign currency translation (FRS-21) identifies two types of foreign operations for translation purposes: an integrated and an independent foreign operation. ${ }^{2}$ The standard provides a brief description of five qualitative factors to assist in determining the classification of a foreign operation and prescribes the method to be used in translating the financial statements of the foreign operation depending on its classification. This classification determines whether exchange differences from translations are included in reported earnings or transferred directly to a reserve (equity) account in the balance sheet. It has been suggested that due to the lack of clarity in the accounting standard, its application results in dissimilar judgements in similar circumstances (e.g.; Mehta and Thapa, 1991; Doupnik and Evans, 1988). It has also been suggested that the application of the standard is biased toward the selection of independent foreign operation designation (e.g., Doupnik and Evans, 1988; Ndubizu, 1987).

To examine the judgement processes of financial controllers, a repeated measures design is used. The factors outlined in the accounting standard on foreign currency translation are used as judgement cues and the respondents are asked to exercise judgement in respect of the

\footnotetext{
1 In New Zealand, see Warbrick and Marra (1987). In the US in May 1978, the FASB issued an invitation for public comment on FASB statements 1 -12. More than 200 letters were received and SFAS 8 was the subject of most of the comments as the respondents nearly unanimously called for changes (Ruland and Doupnik, 1988).

2 SFAS 52 in the US uses the concept of functional currency. The functional currency of a foreign operation is either the local currency or the US dollar. The NZ standard does not refer to the concept of functional currency, but otherwise uses similar terms to SFAS 52. The local and US dollar functional currencies in SFAS 52 are described in the NZ standard as independent and integrated foreign operations, respectively.
} 
designation of hypothetical foreign operations based on the description of the cues. The descriptions of cues are based on the brief explanations in the accounting standard.

The remainder of the paper is organised as follows: Section 2 reviews the accounting standard on foreign currency; Section 3 evaluates the literature; hypotheses are developed in Section 4; research design is discussed in Section 5; and Section 6 presents the results. Summary and conclusions are included in Section 7.

\section{Accounting Standards on Foreign Currency Translations}

In 1987, the New Zealand Society of Accountants issued a Statement of Standard Accounting Practice (SSAP-21) on accounting for foreign currency that provides guidance in respect of translation of foreign operations' financial statements. The standard was revised in 1997 as FRS-21. It identifies two types of foreign operations: independent and integrated. The standard defines independent foreign operations as 'those operations that accumulate cash and other monetary items, incur expenses and costs, realise revenues and perhaps arrange finance, all substantially in the foreign currency.' Integrated foreign operations are described as 'those that are an integral part of the operations of the reporting entity.'

The designation of a foreign operation as independent or integrated determines the translation method and whether exchange differences arising on translation are included as a component of income. An integrated foreign operation's financial statements are translated using the temporal method. Exchange differences are included as a component of income. An independent foreign operation's financial statements are translated using the current rate method. Exchange differences are taken directly to a reserve (equity) account in the balance sheet. ${ }^{3}$

\footnotetext{
3 While the former New Zealand standard (SSAP-21) requires the use of the closing rate method for independent foreign operations, the revised standard (FRS-21) and accounting standards in other countries such as Australia and the US require the use of the current rate. There are minor differences between the closing rate and the current rate methods. For example, revenues and expenses are translated under the closing rate method by using the closing rate while the average rates are used under the current rate method. The New Zealand standard setters chose the closing rate method (SSAP-21) for a number of reasons including simplicity and consistency in the translation of the different elements. It appears that the change to the current rate is motivated by the desire to achieve international harmonisation.
} 
There are minor differences between the NZ standard (FRS-21) and standards on foreign currency in other countries. In determining the nature of a foreign operation as integrated or independent, the NZ standard outlines five of the six factors specified in SFAS 52, ASRB1012 (Australia) and CICA section 1650 (Canada). These factors are: sources of expenses, sources of financing, sources of markets of the foreign operation, volume of transactions between the foreign operation and its parent, and whether cash flows of its parent are insulated from or affected by its operations. SFAS No. 52, ASRB-1012 and CICA section 1650 include a sixth factor regarding whether the 'sales prices' of the foreign operation's products are determined by domestic or external conditions. The NZ standard that was largely based on the then international standard (IAS-21) does not incorporate this factor. IAS 21, which was revised in 1993, now incorporates the 'sales price' factor.

SFAS No. 52, ASRB 1012 and CICA section 1650 require the consideration of the six factors both individually and collectively in determining the designation of a foreign operation. However, the NZ standard requires only the consideration of the five factors. None of the standards provides quantitative thresholds or detailed guidelines of how these factors should be evaluated. ${ }^{4}$ The lack of detailed guidance has raised some concerns. For example, in promulgating SFAS No. 52, the FASB's dissenting members (3 of 7) expressed the concern that the application of the criteria will not result in similar accounting for similar situations. ${ }^{5}$

\footnotetext{
${ }^{4}$ Some accounting standards provide quantitative thresholds to assist in the determination of financial reporting decisions. For example, the $20 \%$ interest in voting power for reporting investment by using the equity method (SSAP-8), the $10 \%$ threshold of assets, revenue and results for identifying reportable segments (SSAP-23), $75 \%$ of useful life and $90 \%$ of fair value for accounting for a lease as a finance lease (SSAP-18), and 90\% of equity acquisition for a combination to be accounted for by using the pooling of interests method (SSAP-8).

5 Similar concerns were raised in NZ during the development of SSAP-21. Approximately $40 \%$ of the submissions on exposure draft (ED-37A) expressed the concern that the qualitative criteria in the standard would lead to dissimilar reporting of similar situations. The development of SSAP-21 was controversial. An exposure draft (ED-37) was first released in June 1986 by the Accounting Standards and Research Board which proposed to require that all foreign operations be translated by using the current method and all exchange differences arising on translation be included in the determination of income. Public submissions on this exposure draft indicated a strong opposition to the proposed requirement that did not consider the nature of a foreign operation in determining the translation method. Lack of consistency with international standards was also cited as a reason for the strong opposition to the proposed standard (Warbrick and Marra, 1987). Because of the unfavourable submissions on ED-37, the exposure draft was replaced with ED-37A in July 1987, which followed requirements similar to SFAS 52 and IAS-21. In July 1987, the board released a provisional standard dealing with only the disclosure of foreign currency. SSAP-21 was issued in April 1988 to apply to accounting periods beginning on or after 1 July 1988.
} 


\section{Literature Review}

Foreign currency translation is an accounting issue that has resulted in substantial literature. This literature covers many issues such as economic consequences and accounting policy choice (for example, Griffin, 1983; Gray, 1984; Ayres, 1986a; Ayres, 1986b, Booth and Rotenberg, 1991; and Bruinstoop and Godfrey, 1992). Houston (1989) provides a comprehensive review of this literature. After reviewing the evidence regarding whether there are economic effects associated with changes in accounting standards on foreign currency in the US, Houston concludes that the results are mixed. Further, she finds that positive accounting theory provides insights into the association between accounting policy choice and firm characteristics.

There is some evidence suggesting that the application of accounting standards on foreign currency results in incomparable financial reporting. Mehta and Thapa (1991) examine the functional currency choice of some US multinational companies and find examples of companies operating in similar economic situations that use different functional currencies in translating the financial statements of their foreign subsidiaries. They argue that the discretion that is granted to management in the accounting standard on foreign currency raises the likelihood of differing accounting methods for similar situations.

To enhance the comparability of financial reporting, Mehta and Thapa recommend, inter alia, reducing the vagueness in the guidelines in the selection of foreign currency translation method. They attribute this vagueness to lack of detail in the accounting standard regarding the relative importance and the absolute magnitude of the determining factors. Amernic and Galvin (1984) suggest that the implementation of the accounting standard is complicated since most foreign operations are neither clearly integrated nor clearly independent. They argue that in such situations pressures other than the desire for fair reporting may influence the judgement decision.

The literature regarding the criteria for determination of the designation of foreign operations and consequently the appropriate translation methods is predominantly opinion based. Evans and Doupnik (1986) survey the views of financial controllers of US based multi-national corporations in respect of the importance of the factors outlined in SFAS 52 and find that the most heavily weighted factor was cash flows, followed by sales market, expense and sales price. 
Doupnik and Evans (1988) evaluate the functional currency decisions of multinational corporations and find that these firms use weighting schemes for the determining factors which bias toward selecting the foreign currency as the functional currency (i.e., independent foreign operations in the NZ standard). They argue that different weighting schemes are used which could be in violation of the spirit of the accounting standard. Further, they conclude that standard-setters should establish more specific guidelines for determining the functional currency that would lead to greater comparability among firms.

Ndubizu (1987) notes that SFAS 52 gives managers the power to determine the functional currency of their foreign operations, and they may use this freedom to reduce the volatility of reported earnings. His survey of managers indicates that they prefer the independent designation offered by SFAS 52 to the integrated designation specified in SFAS 8 because of the impact on earnings' volatility. In a report by the Ontario Securities Commission in Canada and cited in the Ernst \& Young Report on Financial Reporting Developments, 1995, the Commission identified several common problems in financial reporting. One of these problems is that companies classify their foreign operations as self-sustaining for translation purposes when their MD\&A discussions suggest that there are significant integrations between the Canadian parents and their foreign operations.

The research reviewed in this section indicates that foreign currency translation is an important accounting issue because of its economic impact. This literature suggests that the considerable judgement flexibility allowed in accounting standards permits some opportunistic behaviour. However, this judgement process has not been investigated.

Although approximately a decade has passed since the New Zealand standard was first released, an examination of the judgement process is timely for two reasons. First, to appropriately investigate issues relating to judgement, considerable time should pass to allow for a common understanding to emerge. Second, the New Zealand standard on foreign operation (FRS-21) was re-exposed and revised in 1997. Other than for minor re-drafting and the removal of guidance dealing with hedging, the new standard retains the same requirements as in SSAP-21. 


\section{Hypotheses}

Although the New Zealand accounting standard on foreign currency translation provides five factors to evaluate the economic relationship between a reporting entity and its foreign operations, it does not describe the judgement process nor does it indicate the relative importance of each determining factor. Therefore, one of the research questions is to identify the significant factors and their relative contributions to the judgement processes of preparers of financial statements. Although the cues in the NZ standard are similar to those in SFAS 52, the NZ standard does not provide headings or titles for the cues. To shorten the description of the cues in the standard, we use similar cue-headings as in SFAS 52. The abbreviated titles of the cues and their brief descriptions are:

- Expenses: the source of labour, materials and other costs used by the foreign operations is either primarily from $\mathrm{NZ}$ or the local sources;

- Inter-company transactions: the volume of transactions between the parent and the foreign operation is either high or low;

- Financing: the source of financing is mainly from the parent or from the foreign operation's own resources and local borrowings;

- $\quad$ Sales Markets: the market of the foreign operation is mainly within the parent's country (NZ) or outside it; and

- Cash flows: cash flows of the parent are either directly affected by the day-to-day activities of the foreign operation or insulated from such activities.

\subsection{Cue Utilisation}

In assessing the research questions concerning the significance of the experimental factors, the following hypotheses are tested:

H1A: Expenses is significant in the judgement processes of respondents.

H1B: Inter-company transactions is significant in the judgement processes of respondents.

H1C: Financing is significant in the judgement processes of respondents.

H1D: Sales Markets is significant in the judgement processes of respondents.

H1E: Cash flows is significant in the judgement processes of respondents. 
The accounting standard is silent on the relative contribution of the determining factors in the judgement process. Mehta and Thapa, (1991) criticise the standard for not providing such guidance. In the absence of any guidance, it may be assumed that the cues have equal importance. To test whether the determining factors contribute equally to the judgement process, we develop the following hypothesis:

H1F: The factors have equal importance in the judgement of respondents.

\subsection{Consensus}

One of the objectives of promulgating accounting standards is to enhance the comparability of financial reports. This comparability is achieved when similar reporting practices are followed in similar circumstances. In situations involving judgement, such practices emerge when there is consensus among decision-makers. One of the criticisms frequently asserted regarding the accounting standard on foreign currency is that the qualitative cues lead to disagreements among decision-makers and therefore result in lack of consensus.

Judgement consensus could also be regarded as an indicator of judgement validity that cannot be assessed directly since the accounting standards do not describe how the judgement should be made. This issue often arises in judgement studies in accounting contexts (for example, Joyce, 1976; Day and Psaros, 1996). In this study, since it is not possible to determine judgement validity regarding the designation of a foreign operation, judgement consensus could be regarded as a surrogate for judgement validity. Judgement consensus is tested by the following hypothesis:

H2: The respondents exhibit judgement consensus.

\subsection{Consistency}

In addition to consensus, consistency is another indication of judgement validity. Consistency is one of the research questions frequently examined in studies that attempt to model professional judgements. It assesses whether decision-makers are consistent (stable) in their judgements in a test-retest (see, for example, Libby, 1981; Libby and Lewis, 1977; Joyce, 1976). Lack of consistency may indicate that the respondents did not have a clear judgement strategy and/or that they have not taken the task seriously and could justify dropping their 
responses in modelling the judgement process of decision-makers. To assess judgement consistency, the following hypothesis is tested:

H3: The respondents exhibit judgement consistency.

\subsection{Self-Insight}

Self-insight indicates whether respondents understand their own judgement process that is an indication of the existence of judgement strategy. It is another research question relating to judgement validity that is often addressed in judgement modelling studies (Libby and Lewis, 1977). To assess self-insight, the following hypothesis is tested:

H4: The respondents exhibit judgement self-insight.

\subsection{Bias}

Some studies indicate that the choice of a functional currency in foreign currency translation decisions is biased toward selecting an independent classification due to the perceived favourable impact on reported earnings (e. g., Ndubizu, 1987; Doupnik and Evans, 1988). Although this literature criticises the accounting standard for allowing considerable accounting discretion, this bias may be the result of judgement and/or the impact of environmental factors such as managerial incentives. To examine whether the judgement process is inherently biased, we develop the following hypothesis.

H5: The respondents do not exhibit judgement bias.

\section{Research Design}

\subsection{Method}

A repeated measures questionnaire is used to gather data to examine the judgement processes of financial controllers of New Zealand corporations. The design of the experiment is a complete $2^{5}$ factorial design. The judgements of each respondent were captured for each of the 32 stimulus combinations. To assess each subject's judgement consistency, four duplicate 
combinations were selected at random from the thirty-two original combinations and included in the instrument. The 36 combinations are presented randomly in six equal blocks. The experimental cues in each block are also randomly presented. All subjects received identical copies of the instrument.

An interval scale from 1 to 9 measures a respondent's judgement (dependent variable) for each combination, where 1 indicates that the foreign operation is definitely integrated and 9 indicates that the foreign operation is definitely independent. The five factors (independent variables) are dichotomously scaled based on the descriptions provided in the accounting standard and manipulated in an orthogonal analysis of variance design. The independent variables and their dichotomous levels are shown in Panel A of Table 1. Panel B provides an example of a hypothetical judgement set.

Self-insight is often examined by correlating each subject's relative weighting of factors in the judgement model with the subject's own assessment of the relative importance of the determining factors (e.g., Trotman, 1996, p 40; Slovic, 1969; Joyce, 1976; Schultz and Gustavson, 1978). To obtain the subject's assessment of the relative importance of the determining factors, respondents are asked to allocate 100 points among the five experimental factors included in the instrument. Further, in the debriefing section of the instrument, the respondents are asked to list other factors, if any, they consider relevant in determining the nature of foreign operations.

\section{$5.2 \quad$ Subjects}

A total of 243 financial controllers from all 123 listed and 120 largest unlisted public companies were included in the original contact pool. To gather data in respect of expert judgement, the covering letter accompanying the instrument emphasised that the respondents should have knowledge of and experience with foreign currency translations. Useable responses were received from 61 respondents. Seventy one respondents returned blank instruments; 49 of them state that they had no experience with foreign currency translations since their companies had no foreign operations and 21 respondents advise that their companies have a policy of not responding to surveys. ${ }^{6}$ Excluding these respondents from the

\footnotetext{
6 An additional respondent, the financial controller of one of New Zealand's largest listed companies, declined to complete the instrument on the grounds that he and his company do not agree with the accounting standard on foreign currency. He argued that only the closing rate method with the exchange difference transferred directly to a reserve (equity) account should be allowed.
} 
original contact pool results in a response rate of $34 \%$. The respondents average age and work experience are 39 years and 17 years, respectively. 
Table 1

Panel A: Independent Variables and Their Levels

\begin{tabular}{|l|c|c|}
\hline Description & Level 1 & Level 2 \\
& $\begin{array}{c}\text { Indicating integrated } \\
\text { foreign operation }\end{array}$ & $\begin{array}{c}\text { Indicating independent } \\
\text { foreign operation }\end{array}$ \\
\hline $\begin{array}{l}\text { Expenses: the source of labour, materials and other costs used by the } \\
\text { foreign operations is either primarily from NZ or the local sources. }\end{array}$ & NZ & Local \\
\hline $\begin{array}{l}\text { Inter-company transactions: the volume of transactions between the parent } \\
\text { and the foreign operation is either high or low. }\end{array}$ & High & Low \\
\hline $\begin{array}{l}\text { Financing: the source of financing is mainly from the parent or from the } \\
\text { foreign operation's own resources and local borrowings. }\end{array}$ & Local \\
\hline $\begin{array}{l}\text { Sales } \text { Markets: the market of the foreign operation is mainly within the } \\
\text { parent's country (NZ) or outside it. }\end{array}$ & NZ & Outside NZ \\
\hline $\begin{array}{l}\text { Cash flows: cash flows of the parent are either directly affected by the day- } \\
\text { to-day activities of the foreign operation or insulated from such activities. }\end{array}$ & Affected & Insulated \\
\hline
\end{tabular}

\section{Panel B: An Example of a Hypothetical Judgement Set}

\begin{tabular}{|c|c|c|c|c|c|c|c|c|c|c|c|c|c|c|}
\hline \multicolumn{6}{|c|}{ Cues and their descriptions } & \multicolumn{9}{|c|}{ Judgement } \\
\hline & & & & & & \multicolumn{9}{|c|}{ PREFERENCE FOR A FOREIGN OPERATION DESIGNATION } \\
\hline$\underline{\text { Set }}$ & $\underline{\text { Expenses }}$ & Financing & $\underline{\text { Sales Markets }}$ & $\begin{array}{c}\text { Inter-company } \\
\text { transactions }\end{array}$ & $\underline{\text { Cash flows }}$ & \multicolumn{2}{|c|}{$\begin{array}{l}\text { Definitely } \\
\text { integrated }\end{array}$} & & & & & & \multicolumn{2}{|c|}{$\begin{array}{c}\text { Definitely } \\
\text { independent }\end{array}$} \\
\hline$x$ & Local & Parent & Outside NZ & High & Affected & 1 & 2 & 3 & 4 & 5 & 6 & 7 & 8 & 9 \\
\hline
\end{tabular}




\section{Data Analysis and Results}

Hypotheses H1A through H1F are tested by an ANOVA model with the judgement as the dependent variable and the five within-subject cues as independent variables. The relative importance of the factors in the judgement processes is assessed by Hays' omega statistic $\left(\mathrm{w}^{2}\right)$, which expresses the relative contribution of factors to the response variation (Hays, 1973). Table 2 provides F-statistics, corresponding significance levels, and $\mathrm{w}^{2} \mathrm{~s}$ for the model's factors on a pooled group basis. ${ }^{7}$

Table 2

ANOVA Model Results

\begin{tabular}{|c|c|c|c|}
\hline Source & F value & $\operatorname{Pr}>\mathbf{F}$ & 2 \\
\hline \multicolumn{4}{|l|}{ Within-subject factors } \\
\hline (1) Expenses & 242 & 0.0001 & 7 \\
\hline (2) Inter-company transactions & 355 & 0.0001 & 10 \\
\hline (3) Financing & 378 & 0.0001 & 11 \\
\hline (4) Sales markets & 300 & 0.0001 & 9 \\
\hline (5) Cash flows & 245 & 0.0001 & $\underline{7}$ \\
\hline Total within-subject & & & 44 \\
\hline
\end{tabular}

The results at 0.05 significance level indicate that all the judgement factors are significant. Therefore, hypothesis H1A though H1E are supported. ${ }^{8}$

\footnotetext{
${ }^{7}$ A basic assumption of the ANOVA model is that the variances due to experimental error within each of the treatment populations are homogenous. Many studies have concluded, however, that the importance of this assumption was overrated (Stallman, 1969; Winer, 1971, p205) which may explain why this is rarely tested in judgement studies. Using the Cochran C test for homogeneity of variances, as described in Winer (1971, p 208), indicates that the assumption of homogeneity of variance is not violated.

8 A between-subject factor incorporated in the pooled model, whether the subjects' companies have foreign operations, is significant at 0.05 , but its $w^{2}$ is less than $1 \%$. This suggests that the subjects have similar decision making processes irrespective of whether their companies have foreign operations.
} 
The five within-subject factors explain $44 \%$ of the variation in the pooled model as measured by $\mathrm{w}^{2}$. The three marginally more important factors are the 'financing', 'inter-company transactions' and 'sales markets' which explain 11, 10 and 9\% of judgement variation, respectively. The 'expenses' and 'cash flows' factors have similar importance in explaining judgement variation. These results marginally do not support the hypothesis H1F that the cues make equal contributions to the judgement processes of respondents.

The $44 \%$ within subject variance explained by the model is lower than the $51 \%$ within subject variance for the model for judgements concerning long term investments in the study by Laswad and Roush (1996). This lower explanatory power may be explained in terms of the judgement difficulty encountered in this study. Further, it may also be explained in terms of differences in nature of the cues used in the two studies. The determining cues in this study are qualitative while the study by Laswad and Roush (1996) included a highly important quantitative cue.

Reviews of judgements studies in accounting and psychology indicate that the simple linear model appears to characterise adequately the judgement processes of subjects (for example, Libby, 1981; Belkaoui, 1989; Goldberg, 1968). The results in this study are consistent with this literature. There are no significant two-way interactions at 0.05 , which suggests that the cues are not evaluated collectively.

Consensus is the extent of agreement among the respondents in the selection of the nature of foreign operations. Eighty percent of the Pearson product-moment correlation coefficients between the judgements of the respondents are positive and significant at 0.05 . The average correlation coefficient between the judgements of respondents is 0.52 . Coefficients of this magnitude in audit judgements have been described as an indication of a 'moderate degree' of consensus (Libby, 1981, pp. 142-150). In a study regarding judgements involving consolidation statements, Day and Psaros (1996) describe an average Pearson correlation coefficient between all subjects of 0.509 as suggesting 'a reasonably high level of consensus'. This suggests that hypothesis (H2) is supported, and therefore, respondents exhibit judgement consensus.

Consistency is assessed by comparing each subject's responses to the four repeated combinations in a test-retest. Using the Wilcoxon signed ranks test for the matched pairs of responses for each subject does not reject the hypothesis (H3) at 0.01 . The average 
correlation coefficient between the four repeated measures in a test-retest is 0.79 . This suggests a considerable level of judgement consistency that indicates that the respondents took the task seriously and based their decisions on a judgement strategy that support the validity of the judgement processes captured.

Judgement self-insight is examined by comparing the relative importance of cues provided by the ANOVA model with the subjective description of judgement provided by each respondent. The Wilcoxon signed ranks test shows that each subject has exhibited selfinsight since there is no significant difference at 0.01 between each subject's assessment of the importance of each factor and the relative importance of each factor as indicated by Hays' statistic. Further, the average Pearson Product Moment Correlation coefficient between each subject's assessment and her/his Hays' statistic is 0.63. The correlation coefficients for 57 of the 61 subjects are positive and significant at 0.01 . These results support the hypothesis (H4) that the respondents exhibit judgement self-insight.

To examine whether the respondents exhibit judgement bias, we assessed whether each respondent's mean response is significantly different from an unbiased mean response. Since the research design is a complete factorial design, an unbiased response of the measurement scale ( 1 to 9$)$ is 5 . Forty-eight (79\%) respondents' mean responses are not significantly different from the unbiased mean response. Of the 13 remaining respondents whose mean responses differed significantly from the unbiased mean response, only five favour an independent designation. These results supports hypothesis 5 suggesting that the respondents exhibit no bias and in particular no bias favouring independent designations. This suggests that the observed bias described in the literature may have been the outcome of environmental factors such as managerial opportunistic behaviour. We argue that making accounting standards less flexible may not cause this bias to disappear.

In the debriefing section of the instrument, the subjects are asked to list any other factors that have not been included in the accounting standard and which they would consider in classifying foreign operations. Sixteen of the 61 respondents have listed additional factors. All these respondents referred to the concept of whether the activities of foreign operations are carried out with a significant degree of managerial autonomy from their parents. This cue has been included in the revised international standard IAS-21 (1993), and therefore the respondents may have been influenced by this standard. 


\section{Summary and Conclusions}

The standards on foreign currency translation require the identification of the nature of foreign operations to determine the appropriate translation methods of their financial statements. These standards specify only qualitative cues to assist in the determination of the nature of foreign operations. The standards do not describe how judgements should be formed nor do they state the relative importance of the determining cues.

We use a repeated measure research design to examine the judgement of financial controllers in determining the designation of foreign operations. The results indicate that all the determining factors outlined in the NZ accounting standard are significant in the judgement process of respondents. However, the results also indicate that the relative importance of the determining factors are marginally not equal, where 'financing' followed by 'inter-company transactions' and 'sales markets' are the more important factors in the judgement process. The factors, 'expenses' and 'cash flows', appear to have lower levels of importance. These results are different from the results of an opinion survey in the US by Evans and Doupnik (1986) who found that the most weighted factor was 'cash flows', followed by 'sales markets', 'expenses' and 'sales price'. The differences in the results of the two studies may be the outcome of differences in research design (eg, opinion versus judgement) or due to country effect. If the differences are due to country effect, it may suggest that similar standards may be applied differently in different jurisdictions. This suggests that recent proposals for greater international harmonisation of financial reporting may not achieve their objectives by relying solely on harmonisation of accounting standards.

The total variance explained by the ANOVA model in this study $\left(\mathrm{w}^{2}=44 \%\right)$ is lower than the total within-subject variance in the Laswad and Roush (1996) study which examines judgements in respect of accounting for investments $\left(\mathrm{w}^{2}=59 \%\right)$. This difference may be attributed to the existence of a quantitative factor in the second study. This suggests that quantitative factors assist in reducing judgement variability more than qualitative factors in the judgement models of subjects. This implies that providing quantitative factors in accounting standards improves consistency and comparability in financial reporting.

The assertions suggesting that the ambiguous nature of the standard on foreign currency would lead to different judgements in similar circumstances are not supported. These results indicate that the respondents have exhibited consensus, consistency and self-insight. Since 
almost a decade has passed since the standard was released in New Zealand, these results may indicate that there has been considerable learning experience that may have produced these results.

However, this high judgement consensus may be overstated. The judgements in this study are assessed using a continuous scale, but decisions based on the standard are dichotomous (either integrated or independent). It is possible that in a situation where a foreign operation is not clearly integrated nor independent, two decision-makers may reach a similar judgement using the continuous scale, but disagree on a dichotomous decision. Amernic and Galvin's (1984) survey suggests that a high proportion of foreign operations of Canadian companies is neither clearly independent nor clearly integrated. . Amernic and Galvin suggest that economic incentives may influence judgement decisions in these circumstances. The results generally indicate that the judgement of respondents is not biased toward either classification of foreign operations. This suggests that the observed biases found in other studies may be the outcome of economic incentives rather than the outcome of judgement processes in the application of accounting standards. Future research may consider the interaction between the judgement processes and the application of accounting standards and other environmental factors such as management incentives.

The information from the debriefing section of the instrument suggests that there are other determining factors that have not been included in the accounting standard. A factor that is frequently suggested by the subjects is the managerial independence of the foreign operation. Standard setters may consider incorporating this factor in future revisions of the standard. 


\section{References}

Amernic, J., and Galvin, B. (1984) Implementing the New Foreign Currency Rules in Canada and the United States: A Challenge to Professional Judgement. International Journal of Accounting.

Ayres, F. (1986a) Characteristics of Firms Electing Early Adoption of SFAS 52. Journal of Accounting and Economics.

Ayres, F. A. (1986b) Comment on Corporate Preferences for Foreign Currency Accounting Standards. Journal of Accounting Research, Spring.

Belkaoui, A. (1989) Human Information Processing in Accounting. Quorum Books.

Booth, L., and Rotenberg W.(1991) Evidence on Corporate Preferences for Foreign Currency Accounting Standards. Journal of International Financial Management and Accounting.

Bruinstroop, P. and Godfrey J. (1992) Foreign Currency Accounting Regulation in Australia: Responses of the Resources Sector. Accounting and Business Research.

Chen, A., Comiskey, E. and Mulford C. (1990) Foreign Currency Translation and Analyst Forecast Dispersion: Examining the Effects of Statement of Financial Accounting Standards No. 52. Journal of Accounting and Public Policy.

Day, R. and Psaros J. (1996) A Study of Accountants' Judgments with Respect to the Provision of Consolidated Financial Statements. Abacus.

Doupnik, T. and Evans T. (1988) The Functional Currency Determination: A Strategy To Smooth Income. Advances in International Accounting.

Ernst \& Young (1995) 1995 Financial Reporting Developments, Ernst \& Young (Canada).

Evans and Doupnik (1986) Determining the Future Currency Under Statement 52. Research Report, FASB.

Financial Accounting Standards Board, SFAS No. 52, 'Foreign Currency Translation', 1981.

Garlicki, T., Fabozzi, F. and Fonfeder R. (1987) The Impact of Earnings Under FASB 52 on Equity Returns., Financial Management.

Goldberg, L.R. (1968) Simple Models or Simple Processes? Some Research on Clinical Judgments, American Psychologist.

Gray, D. (1984) Corporate Preferences for Foreign Currency Accounting Standards. Journal of Accounting Research. 
Griffin, P. (1982) Foreign Exchange Gains and Losses: Impact on Reported Earnings, Abacus.

Griffin, P. (1983) Management's Preferences for FASB Statement No. 52: Predictive Ability Results. Abacus.

Hays, W.L. (1973) Statistics for the social sciences, Holt. Rinehart and Winston, Inc.: New York.

Houston, C. (1989) Foreign Currency Translation Research: Review and Synthesis. Journal of Accounting Literature.

Joyce, E. (1976) Expert Judgement in Audit Program Planning. Journal of Accounting Research, Supplement.

Kelly, L. (1985) Corporate Management Lobbying on FAS No. 8: Some Further Evidence. Journal of Accounting Research, Vol. 23, (2).

Kirsch, R., Evans, T. and Doupnik T. (1990) FASB Statement 52, An Accounting Policy Intervention: U.S.-Based Multinational Corporate Preenactment Lobbying Behavior, Advances in International Accounting.

Laswad, F. and Roush M. (1996) Judgement of Significant Influence by Financial Controllers. Accounting and Finance, November.

Libby, R. (1981) Accounting and Human Information Processing: Theory and Applications, Contemporary Topics in Accounting Series. Prentice-Hall: Englewood Cliffs, New Jersey.

Libby, R. and Lewis B. (1997) Human Information Processing Research in Accounting: The State of the Art, Accounting, Organisations and Society.

Mehta, D. and Thapa S. (1991) FAS-52, Functional Currency, And The Non-Comparability Of Financial Reports. International Journal of Accounting.

Ndubizu, G. A. Management Preferences for Foreign Currency Standards: An Empirical Analysis. International Journal of Accounting.

New Zealand Society of Accountants, 1988 Statement of Standard Accounting Practice No. 21, 'Accounting for the Effects of Changes in Foreign Currency Exchange Rates'.

Ruland, R. and Doupnik T. (1988) Foreign Currency Translation and the Behaviour of Exchange Rates. Journal of International Business Studies, Fall.

Schultz, J. and Gustavson S. (1978) Actuaries' Perceptions of Variables Affecting the Independent Auditor's Legal Liability. The Accounting Review.

Slovic, P. (1969) Analyzing the Expert Judge: A Descriptive Study of a Stockbroker's Decision Processes. Journal of Applied Psychology.

Stallman, J.C. (1969) Toward Experimental Criteria for Judging Disclosure Improvement. Empirical Research in Accounting: Selected Studies 1969, Supplement to Vol 7, Journal of Accounting Research. 
Trotman, K. (1996) Research Methods for Judgment and Decision Making Studies in Auditing. Coopers and Lybrand Research Methodology Monograph No. 3, Coopers and Lybrand.

Warbrick, S. and Marra P. (1987) Changes in Foreign Currencies with Particular Reference to Translation Gains and Losses. Accountants Journal, September.

Winer, B.J. (1971) Statistical Principles in Experimental Design, McGraw-Hill Book Company.

Ziebart, D. and Kim D. (1987) An Examination of the Market Reactions Associated with SFAS No. 8 and SFAS No. 52. The Accounting Review. 